\title{
Uji Daya Hambat Ekstrak Ikan Nike (Awous melanocephalus) Terhadap Pertumbuhan Bakteri Fusobacterium nucleatum
}

\author{
Stevia E. Nonutu, Damajanty H. C. Pangemanan, Christy N. Mintjelungan
}

Program Studi Pendidikan Dokter Gigi Fakultas Kedokteran Universitas Sam Ratulangi, Manado, Indonesia

Email: stevia.nonutu@gmail.com

\begin{abstract}
One of the treatment options of periodontal abscess caused by Fusobacterium nucleatum is administration of antibiotics. However, long-term antibiotics consumption can cause negative side effects. Therefore, alternative treatments that have low side effects and easy to be obtained are needed. Nike fish (Awaous melanocephalus) is one of the endemic fish of North Sulawesi province which has antibacterial properties. This study was aimed to evaluate the inhibition effect of nike fish extract on the growth of Fusobacterium nucleatum. This was a true experimental study with a posttest only control group design. We used modified Kirby-Bauer method with filter papers. Ciprofloxacin was used as the positive control and aquadest as the negative control. Extract of nike fish and stock of pure bacteria Fusobacterium nucleatum were prepared. The results showed that the average diameters of the inhibition zones formed in the nike fish extract after three repetitions, were as follows: for extract concentration of $12.5 \%$ was 2.91 $\mathrm{mm} ; 25 \%$ was $4.16 \mathrm{~mm} ; 50 \%$ was $8.41 \mathrm{~mm}$; and $100 \%$ was $9.58 \mathrm{~mm}$. In conclusion, nike fish extract (Awaous melanocephalus) at concentrations of $50 \%$ and $100 \%$ had a weak inhibitory effect (Himedia category) on the growth of Fusobacterium nucleatum meanwhile at concentrations of $12.5 \%$ and $25 \%$ there was no activity of zone of inhibition.
\end{abstract}

Keywords: extract of nike fish (Awaous melanocephalus); Fusobacterium nucleatum; inhibitory effect

\begin{abstract}
Abstrak: Salah satu opsi pengobatan abses periodontal yang disebabkan oleh bakteri Fusobacterium nucleatum yaitu dengan penggunaan antibiotik namun mengonsumsi antibiotik jangka panjang dapat menimbulkan efek samping negatif. Oleh karena itu, diperlukan pengobatan alternatif yang memiliki efek samping rendah serta mudah didapat. Ikan nike merupakan salah satu ikan endemik Provinsi Sulawesi Utara yang berkhasiat sebagai antibakteri. Penelitian ini bertujuan untuk mengetahui daya hambat ekstrak ikan nike (Awaous melanocephalus) terhadap pertumbuhan bakteri Fusobacterium nucleatum. Jenis penelitian ialah eksperimental murni dengan post test only control group design. Metode yang digunakan yaitu metode modifikasi Kirby-Bauer dengan menggunakan paper disk. Kontrol positif menggunakan antibakteri ciprofloxacin dan kontrol negatif menggunakan akuades. Pada penelitian ini digunakan ekstrak ikan nike dan stok bakteri murni Fusobacterium nucleatum. Hasil penelitian menunjukkan bahwa rerata diameter zona hambat yang terbentuk pada ekstrak ikan nike setelah tiga kali pengulangan yaitu untuk konsentrasi $12,5 \%$ sebesar 2,91 mm; $25 \%$ sebesar 4,16 mm; $50 \%$ sebesar 8,41 mm; dan $100 \%$ sebesar $9,58 \mathrm{~mm}$. Simpulan penelitian ini ialah ekstrak ikan nike (Awaous melanocephalus) pada konsentrasi $50 \%$ dan $100 \%$ memiliki daya hambat kategori lemah (Himedia) terhadap pertumbuhan bakteri Fusobacterium nucleatum sedangkan pada konsentrasi $12,5 \%$ dan $25 \%$ dikategorikan tidak terdapat aktivitas zona hambat.
\end{abstract}

Kata kunci: ekstrak ikan nike (Awaous melanocephalus); Fusobacterium nucleatum; daya hambat 


\section{PENDAHULUAN}

Kesehatan gigi dan mulut mempunyai peranan penting dalam meningkatkan kesejahteraan seseorang. Setiap kegiatan seharihari seperti makan, minum, bicara, dan bersosialisasi membutuhkan keadaan gigi dan mulut yang baik namun sebagian masyarakat cenderung mengabaikan kesehatan rongga mulutnya sehingga menimbulkan masalah kesehatan gigi dan mulut yang serius.

Angka kejadian masalah kesehatan gigi dan mulut di Indonesia masih tergolong tinggi. Berdasarkan Riset Kesehatan Dasar (Riskesdas) pada tahun 2018, prevalensi penyakit gigi dan mulut di Indonesia mencapai $57,6 \%$ dan salah satu kasus terbanyak yaitu penyakit periodontal dengan prevalensi sebesar $96.58 \% .{ }^{1}$ Penyakit periodontal ketiga yang paling sering terjadi yaitu abses periodontal, dengan angka persentase mencapai $7-14 \%$ kasus pada pasien-pasien di klinik gigi. ${ }^{2}$

Abses periodontal merupakan salah satu kondisi klinik berupa suatu inflamasi purulen yang terlokalisir pada jaringan periodonsium yang disebabkan oleh infeksi bakteri. ${ }^{2}$ Fusobacterium nucleatum merupakan salah satu bakteri penyebab abses periodontal. Bakteri ini merupakan bakteri anaerob Gram negatif berbentuk batang yang umumnya ditemukan pada plak pangkal gigi dan dapat merusak jaringan sekitar gigi serta menyebabkan peradangan pada jaringan periodontal. ${ }^{3-5}$

Salah satu indikasi pengobatan untuk menangani abses periodontal yaitu dengan antibiotik. Antibiotik merupakan kelompok obat yang digunakan untuk mengatasi dan mencegah infeksi bakteri namun penggunaan antibiotik dalam jangka waktu panjang dapat menimbulkan berbagai efek samping negatif seperti gangguan pencernaan, alergi, infeksi jamur, perubahan warna gigi, dan resistensi antibiotik. ${ }^{6,7}$

Terdapat berbagai cara pengobatan tradisional yang telah berkembang di Indonesia. Pengobatan tradisional sendiri memiliki efek samping yang rendah sehingga lebih aman bagi tubuh dan mudah untuk didapat. Saat ini telah banyak penelitian yang dilakukan dengan menggunakan sumber daya alam perairan di Indonesia sebagai alternatif dalam bidang medis dan pengobatan. Sulawesi Utara merupakan salah satu Provinsi di Indonesia yang terkenal dengan sumber daya alam perairannya yang melimpah. Ikan nike merupakan salah satu jenis ikan endemik di perairan Provinsi Sulawesi Utara yang berkhasiat sebagai antibakteri karena terdapat kandungan senyawa antibakteri seperti musin, lesitin, dan protease. ${ }^{8}$

Penelitian mengenai potensi mukus ikan nike sebagai antibakteri telah dilakukan oleh Dwirahayu ${ }^{8}$ pada tahun 2018 yang melaporkan bahwa ikan nike memiliki efek antibakteri terhadap bakteri Staphylococcus aureus dan Echerichia coli. Berdasarkan latar belakang yang dipaparkan maka penulis tertarik untuk meneliti uji daya hambat ekstrak ikan nike (Awaous melanocephalus) terhadap pertumbuhan bakteri Fusobacterium nucleatum.

\section{METODE PENELITIAN}

Penelitian ini dilaksanakan di Laboratorium Farmasi Fakultas MIPA Universitas Sam Ratulangi Manado pada bulan JanuariJuni 2021. Jenis penelitian ini ialah eksperimental murni (true experimental design) dengan posttest only control group design. Subjek penelitian yaitu bakteri Fusobacterium nucleatum. Metode yang digunakan yaitu metode Kirby-Bauer dengan menggunakan paper disk. Bakeri Fusobacterium nucleatum yang disimpan pada media tanam Nutrient Broth (NB) diambil dari stok bakteri murni di Laboratorium Mikrobiologi Fakultas Kedokteran Universitas Brawijaya Malang.

Bakeri Fusobacterium nucleatum diambil dengan jarum ose, lalu diletakkan pada Nutrient Broth (NB) miring dengan cara menggores. Bakteri diinkubasi dalam inkubator pada suhu $37^{\circ} \mathrm{C}$ selama $1 \times 24$ jam kemudian bakteri tersebut dibuat suspensenya dengan cara melarutkan $\mathrm{NaCl} 0,9 \%$ sampai kekeruhannya sesuai dengan standar kekeruhan McFarland.

Suspensi bakteri kemudian dimasukkan ke dalam media tanam setelah itu dibuat 
kelompok kontrol dengan cara paper disk pertama dicelupkan pada ekstrak ikan nike (Awaous melanocephalus) dengan konsentrasi $12,5 \%, 25 \%, 50 \%$, dan $100 \%$ kemudian diletakan diatas media MHA yang sudah ditanamkan bakteri. Paper disk kedua yaitu paper disk yang sudah berisi sediaan antibiotik ciprofloxacin, kemudian paper disk ketiga dicelupkan pada kontrol negatif yaitu akuades. Setelah itu cawan Petri diinkubasi dalam inkubator dengan suhu $37^{\circ} \mathrm{C}$ selama 1x24 jam.

Klasifikasi zona hambat yang digunakan yaitu: $<4 \mathrm{~mm}$, tidak ada aktivitas; 5-9 $\mathrm{mm}$, lemah; 10-14 mm, sedang; dan >15 mm, kuat. ${ }^{9}$ Diameter zona hambat diukur menggunakan rumus:

$\frac{D_{\mathrm{v}}+\mathrm{D}_{\mathrm{h}}}{2}$

Gambar 1 menunjukkan cara pengukuran diameter zona hambat. ${ }^{10}$

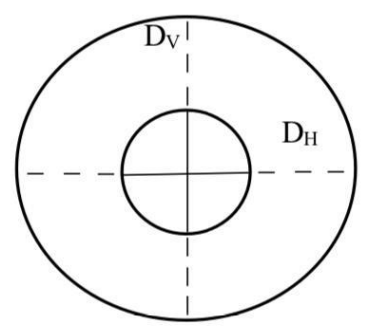

Gambar 1. Pengukuran diameter zona hambat. Sumber: Rahayu, 2019. ${ }^{10}$

$D_{\mathrm{v}}$ : Diameter vertikal, $\mathrm{D}_{\mathrm{H}}$ : Diameter horizontal

\section{HASIL PENELITIAN}

Hasil inkubasi cawan petri selama $1 \mathrm{x}$ 24 jam dengan suhu $37^{\circ} \mathrm{C}$ kemudian dihitung zona hambat yang terbentuk meng- gunakan jangka sorong dalam satuan millimeter $(\mathrm{mm})$. Tabel 1 memperlihatkan hasil rerata diameter zona hambat yang terbentuk.

\section{BAHASAN}

Penelitian ini merupakan uji eksperimental laboratorik untuk mengetahui efek aktivitas antibakteri dari ekstrak ikan nike (Awaous melanocephalus) terhadap bakteri Fusobacterium nucleatum. Penelitian ini dilakukan dengan cara membiakkan bakteri Fusobacterium nucleatum dalam media tanam berupa Muller-Hinton Agar (MHA) disertai dengan peletakan paper disk yang direndam pada ekstrak ikan nike dengan konsentrasi 12,5\%, 25\%, 50\% dan 100\%, peletakan paper disk yang direndam pada akuades sebagai kontrol negatif, dan sediaan paper disk yang sudah berisi antibakteri ciprofloxacin kemudian diinkubasi selama 1 x 24 jam dengan suhu $37^{\circ} \mathrm{C}$.

Pada hasil pengamatan terhadap tiga cawan Petri terlihat adanya zona hambat yang terbentuk di sekitar paper disk yang diberi ekstrak ikan nike. Rerata diameter zona hambat yang terbentuk pada ekstrak ikan nike setelah 3 kali pengulangan yaitu untuk konsentrasi $12,5 \%$ sebesar 2,91 mm; konsentrasi $25 \%$ sebesar 4,16 mm; konsentrasi $50 \%$ sebesar $8,41 \mathrm{~mm}$; dan konsentrasi $100 \%$ sebesar $9,58 \mathrm{~mm}$. Rerata diameter zona hambat ini diukur menggunakan skala sensitivitas (Himedia) dan hasil untuk konsentrasi $50 \%$ dan $100 \%$ termasuk dalam kategori zona hambat lemah sedangkan untuk konsentrasi $12,5 \%$ dan $25 \%$ tidak ada aktifitas zona hambat.

Tabel 1. Hasil pengukuran rerata diameter zona hambat bakteri Fusobacterium nucleatum

\begin{tabular}{ccccccc}
\hline \multicolumn{7}{c}{ Diameter zona hambat (mm) } \\
Penstrak ikan nike & Kontrol positif & $\begin{array}{c}\text { Kontrol negatif } \\
\text { (Akuades) }\end{array}$ \\
\hline 1 & 6 & 3,25 & 9 & 10 & 9,51 & 0 \\
(Awaous melanocephalus) & $100 \%$ & (Ciprofloxacin) & (10) \\
2 & 2,75 & 6,25 & 8,25 & 9,5 & 13,5 & 0 \\
3 & 0 & 3 & 8 & 9,25 & 9,21 & 0 \\
Rerata & 2,91 & 4,16 & 8,41 & 9,58 & 10,74 & 0 \\
\hline
\end{tabular}


Hasil dari ketiga paper disk tersebut menunjukkan bahwa paper disk yang berisi ekstrak ikan nike memiliki diameter zona hambat lebih kecil dari paper disk yang berisi antibakteri ciprofloxacin sedangkan paper disk yang berisi akuades tidak menunjukkan adanya zona hambat. Hasil diameter zona hambat ekstrak ikan nike lebih kecil daripada antibakteri ciprofloxacin yang telah diketahui yaitu $32 \mu \mathrm{g} / \mathrm{ml}$ sedangkan untuk kemampuan ekstrak ikan nike belum diketahui konsentrasi yang sesuai untuk menghambat bakteri Fusobacterium nucleatum.

Zona hambat yang terbentuk di sekitar paper disk berisi ekstrak ikan nike dapat disebabkan oleh mukus ikan nike yang mengandung senyawa antibakteri berupa musin, lesitin, dan protease. ${ }^{8}$ Mukus pada ikan nike terdiri dari air dan makromolekul pembentuk gel termasuk musin dan glikoprotein lainnya. Lapisan mukus pada permukaan ikan ini memiliki sejumlah fungsi yaitu dalam menjaga ketahanan terhadap penyakit, respirasi ion, regulasi osmotik gerak, reproduksi dan komunikasi.

Senyawa biologis aktif seperti musin, lesitin, dan protease dapat memberikan perlindungan pada ikan terhadap potensi mikroba patogen dan parasit. Musin merupakan protein berbentuk lendir dan memiliki karakteristik untuk membentuk, memroduksi, serta mengeluarkan gel yang berfungsi sebagai pelumas untuk menghambat molekul asing yang akan masuk ke dalam tubuh. Protein pada musin bekerja melalui interaksi secara negatif dengan fosfolipid pada membran sel bakteri yang diikuti oleh kerusakan fisik pada bakteri. Selanjutnya protein bekerja melalui ikatan dengan membran fosfolipid pada permukaan bakteri yang kaya akan muatan ion negatif dan menyebabkan kandungan intrasel bakteri mengalami lisis. Lesitin merupakan senyawa antibakteri yang mampu memberikan perlindungan dari patogen bakteri dan juga parasit dengan mekanisme penghambatan bakteri berupa perusakan dinding sel dengan cara menghambat sintesis sel mikroba, merusak keutuhan dinding sel mikroba, dan menghambat sintesis protein sel mikroba. Kandungan enzim protease pada ikan nike juga mempunyai aktivitas antibakteri yang kuat; hal ini disebabkan oleh enzim protease dalam mukus ikan ini akan bekerja melalui aktivitas gen yang mengkode protein antimikroba serta protein komplementer maupun dengan mekanisme yang melibatkan turunan AMPs seperti pembukaan saluran atau pori serta gangguan dan penghambatan pada dinding sel bakteri. ${ }^{11-13}$

Uji daya hambat dari ekstrak ikan nike terhadap pertumbuhan bakteri Fusobacterium nucleatum merupakan penelitian yang belum pernah dilakukan sebelumnya. Pada penelitian yang dilakukan oleh Dwirahayu ${ }^{8}$ di Gorontalo mengenai potensi ikan nike (Awaous melanocephalus) sebagai antibakteri, bakteri yang digunakan yaitu Staphylococcus aureus dan Echerichia coli. Hasil penelitian tersebut mendapatkan bahwa mukus ikan nike (Awaous melanocephalus) memiliki efek antibakteri terhadap Staphylococcus aureus dan Echerichia coli. Penelitian lainnya yang dilakukan oleh Kumaji dan Zakaria ${ }^{14}$ di Gorontalo terhadap potensi antibakteri mukus ikan-ikan native diperairan danau Limboto. Pada penelitian tersebut ikan yang diteliti ialah famili Gobiidae, Siluridae, dan Eleotridae sedangkan bakteri yang digunakan yaitu bakteri Staphylococcus aureus dan Vibrio alginolyticus. Hasil penelitiannya menunjukkan bahwa ikan-ikan tersebut dapat menghambat pertumbuhan bakteri Staphylococcus aureus dan Vibrio alginolyticus. Penelitian mengenai aktivitas antibakteri pada mukus dari beberapa ikan air tawar memang telah banyak dilakukan namun hanya dilakukan pada ikan-ikan introduksi seperti ikan lele, ikan belut, dan ikan nila sedangkan untuk penelitian mengenai aktivitas antibakteri pada ikan-ikan native seperti ikan nike, ikan stiphodon, dan ikan manggabai masih sangat minim sehingga perlu dilakukan eksplorasi lebih lanjut. ${ }^{15}$

Antibakteri ciprofloxacin digunakan sebagai kontrol positif karena di Indonesia ciprofloxacin merupakan salah satu antibiotik golongan floroquinolon yang paling banyak digunakan. Floroquinolon merupa- 
kan salah satu antibiotik berspektrum luas untuk terapi infeksi dan memiliki kepekaan terhadap semua bakteri di antaranya bakteri Gram negatif dan bakteri Gram positif. ${ }^{16}$

Penelitian ini memperlihatkan bahwa ekstrak ikan nike (Awaous melanocephalus) memiliki daya hambat terhadap partumbuhan bakteri Fusobacterium nucleatum walaupun dengan zona hambat yang lebih kecil dibandingkan dengan antibakteri ciprofloxacin. Hal ini menunjukkan adanya senyawa antibakteri pada ekstrak ikan nike (Awaous melanocephalus).

\section{SIMPULAN}

Ekstrak ikan nike (Awaous melanocephalus) memiliki daya hambat terhadap bakteri Fusobacterium nucleatum dengan rerata zona hambat yang terbentuk sebesar 9,58 mm pada konsentrasi $100 \%$ dan 8,41 mm pada konsentrasi $50 \%$ yang termasuk dalam kategori zona hambat lemah menurut skala sensitivitas Himedia.

Penelitian lanjut mengenai uji daya hambat kadar minimum ekstrak ikan nike (Awaous melanocephalus) terhadap pertumbuhan bakteri Fusobacterium nucleatum perlu dikembangkan agar konsentrasi hambat minimum (KHM) dapat ditentukan dengan menggunakan metode konsentrasi bertingkat. Selain itu, dibutuhkan penelitian lebih lanjut untuk mengeksplorasi kandungan senyawa-senyawa kimia berkhasiat dalam ekstrak ikan nike (Awaous melanocephalus).

\section{Konflik Kepentingan}

Penulis menyatakan tidak terdapat konflik kepentingan dalam studi ini.

\section{DAFTAR PUSTAKA}

1. Badan Penelitian dan Pengembangan Kesehatan. Hasil utama Riskesdas 2018. Jakarta: Kementerian Kesehatan RI, 2018; p. 94, 207.

2. Manson JD, Eley BM. Buku Ajar Periodonti. Jakarta: Hipokrates, 2013; p. 44- 67.

3. Carranza FA, Newman MG, Takel HH, Klokkevold PR. Carranza's Clinical Periodontology (13th ed). Canada:
Elsevier, 2019.

4. Boleng DT. Bakteriologi Konsep-konsep Dasar. Malang: UMM Press, 2015; p. 102.

5. Punit VP, Sheela KG, Amrita P. Periodontal abscess: a review. J Clin Diagn Res. 2011;5(2):404-9.

6. Siregar FD. Abses Periodontal. Medan: Universitas Sumatera Utara, 2011; p. 1-5.

7. Kementerian Kesehatan RI. Pedoman Penggunaan Antibiotik. Jakarta: Departemen Kesehatan RI, 2011.

8. Dwirahayu IP. Potensi mucus ikan nike (Awaous melanocephalus) sebagai antibakteri [Skripsi]. Gorontalo: Universitas Negeri Gorontalo; 2018.

9. McGinnis, Ronalde MG, Lorian V. Antibiotics in Laboratory Medicine (4th ed). Baltimore: Williams \& Wilkins, 1996; p. $177-8$.

10. Rahayu MP. Uji daya hambat ekstrak tinta cumi-cumi (Loligi $s p$ ) terhadap partumbuhan bakteri Staphylococcus aureus. eBiomedik. 2019;7(2):76-80.

11. Yusuf N. Karakterisasi gizi dan pendugaan umur simpan savory chips ikan nike (Awous melanocephalus) [Tesis]. Bogor: Sekolah Pascasarjana Institut Pertanian Bogor; 2011.

12. Islam M, Hossain M, Shoumo K. Competitive antibacterial activity of two Indian major carps and two Chinese carps fish mucus against common pathogenic bacteria at aquaculture pond. Int J Fish Aquat Stud. 2014:2(2):158-62.

13. Hiwarale DK, Khillare YK, Wagh U, Sawant J, Magare M. Assessment of antimicrobial properties of fish mucus. World J Pharm Pharm Sci. 2016:5(5): 666-72.

14. Kumaji SS, Zakaria Z. Potensi antibakteri mucus ikan-ikan native di perairan danau Limboto. Bioeksperimen. 2019; 5(1):55-9.

15. Wei OY, Xavier R, Marimuthu K. Screening of antibacterial activity of mucus extract of snakehead fish, Channa striatus (Bloch). Eur Rev Med Pharmacol Sci. 2010:14:675-81.

16. Chudlori B, Kuswandi M, Indrayudha P. Pola kuman dan resistensinya terhadap antibiotika dari specimen pus di RSUD Dr. Moewardi tahun 2012. Pharmacon. 2012:13(2):70-6. 